by Young-Gyun Kim', Sookwan Kim², Dong-Hun Lee ${ }^{3}$, Yung Mi Lee , Hyoung Jun Kim²,

Seung-Goo Kang ${ }^{2}$, and Young Keun Jin ${ }^{2 *}$

\title{
Occurrence of active gas hydrate mounds in the southwestern slope of the Chukchi Plateau, Arctic Ocean
}

\author{
${ }^{1}$ Research Institute of Earth Resources, Kangwon National University, Chuncheon 24341, Republic of Korea \\ ${ }^{2}$ Division of Polar Earth-system Sciences, Korea Polar Research Institute, Incheon 21990, Republic of Korea; Corresponding author, E-mail: \\ ykjin@kopri.re.kr \\ ${ }^{3}$ Department of Marine Sciences and Convergent Technology, Hanyang University, Ansan 15588, Republic of Korea \\ ${ }^{4}$ Division of Polar Life Sciences, Korea Polar Research Institute, Incheon 21990, Republic of Korea
}

(Received: August 21, 2019; Revised accepted: March 26, 2020)

https://doi.org/10.18814/epiiugs/2020/020053

This study documents the discovery of mound morphologies containing gas hydrate and methane-derived authigenic carbonate (MDAC) in the southwestern slope of the Chukchi Plateau, during the IBRV Araon expeditions in 2016 and 2018. A multibeam bathymetric surveying was the basis for a new and detailed rendering around the mounds. Sub-bottom profiles and site-targeted gravity cores were also collected across these mounds which were located at water depths between $780 \mathrm{~m}$ and $580 \mathrm{~m}$. Mounds are characterized by a circular plan shape of hundreds of meters in width and tens of meters in height. Below the mounds, gas accumulation in the sediment produces acoustic blanking in seismic data. MDACs are identified along the core collected from the top of a mound structure, indicating past methane oxidation processes. Gas hydrate has also been observed at the bottom of the core. Reverse geothermal gradients of the mound support the idea of active presentday seepage. We argue that the prolonged seepage activity of methane-rich fluid, possibly related to the formation of the rifted North Chukchi Basin, has led to the formation of the gas hydrate mounds, named hereafter the Araon Mounds, in the vicinity of the basin margin.

\section{Introduction}

There have been numerous reports of the existence of natural gas hydrates in the continental margins of the world ocean and the origins and distributions thereof vary across geological settings (Kvenvolden and Lorenson, 2013). Marine gas hydrate has long been considered as a potential factor controlling climate on geologic time scales (Sloan et al., 1992; Kennett et al., 2003; Ruppel, 2011), given its high content of methane and its widespread occurrence along continental margins worldwide (Kvenvolden, 1988; Kvenvolden et al., 1993; Klauda and Sandler, 2005). Methane-related phenomena such as bottom-simulating reflectors, gas seepage, high concentrations of methane in sediments, seawater, and at the sea surface, occurrences of gas hydrates, and methane-derived authigenic carbonate (MDAC) have also been reported over the marginal Arctic seas (e.g., Andreassen et al., 1995; Collett and Dallimore, 2003; Petersen et al., 2010; Shakhova et al., 2010). However, information on the central Arctic Ocean remains fragmentary because of harsh sea ice conditions inhibiting data collection.

High-resolution geophysical data from multibeam echo sounding (MBES) and sub-bottom profiling (SBP) surveys can enhance our understanding of methane-related phenomena by revealing the characteristic acoustic signatures of gas- or hydrate-bearing sediments (e.g., Paull et al., 2008; Wilson et al., 2014). Acoustic evidence for the occurrence of gas-related phenomena includes acoustic flare in the water column and acoustic blanking below the seafloor (Jin et al., 2011). Additional data, however, are required to determine the gas types and their origins, such as data from geochemical analysis of the gas or porewater, or of the hydrate itself (e.g., Kim et al., 2013a). Therefore, interdisciplinary marine expeditions are needed to comprehend the nature of areas where seafloor methane seepage occurs.

During the ARA07C expedition onboard the "IBRV Araon" in the summer of 2016, a few mound morphologies were discovered in the southwestern slope of the Chukchi Plateau using MBES, while sailing south to avoid the sea ice (Fig. 1; Jin and Onboard ship scientific party, 2017). Their mound shape and acoustic blanking below the crest gave the impression of an extruded structure related to gas. During our revisit onboard the ARA09C expedition in the summer of 2018, detailed bathymetric mapping over an area of approximately $500 \mathrm{~km}^{2}$ was carried out to identify their occurrence and distribution along the slope (Jin and Shipboard scientific party, 2019). We observed several mound morphologies with acoustic blanking below the crest at certain depth intervals. To obtain the geochemical and stratigraphic information to unravel the origin of the mound morphologies, sediment cores were retrieved from the chosen mounds. Furthermore, we measured the heat flow to obtain the current seeping activity of the mounds. 
a

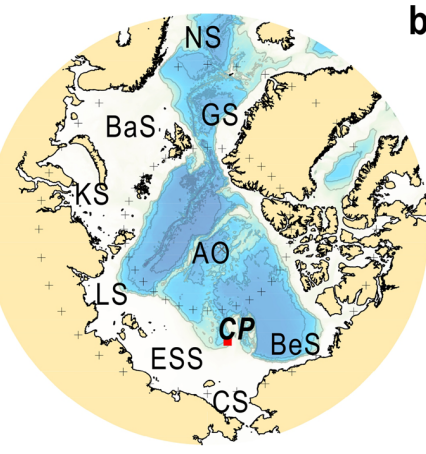

Wrangel-Herald Arch thrust front

$\rightarrow \quad$ Northern limit of Brooks Range frontal thrust belt (Paleogene)

- Normal faults

$\cdots$ Boundary of the Northern Chukchi Basin

$\therefore$ Basin axis

- Extending direction

Study area Multichannel seismic line Subbottom profiler line

$\star$ Station

- Authigenic carbonate b

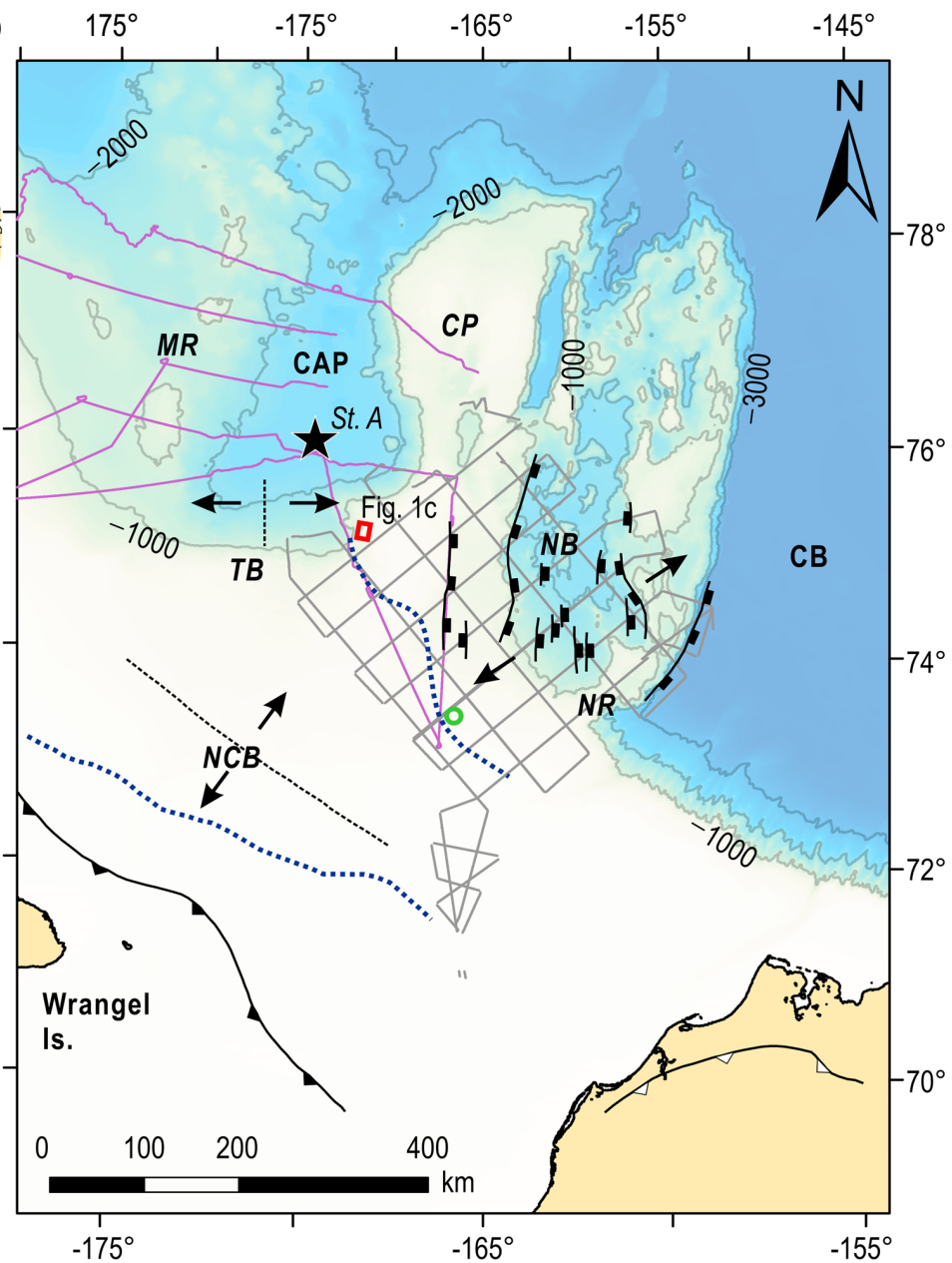

$-175^{\circ}$ $-155^{\circ}$

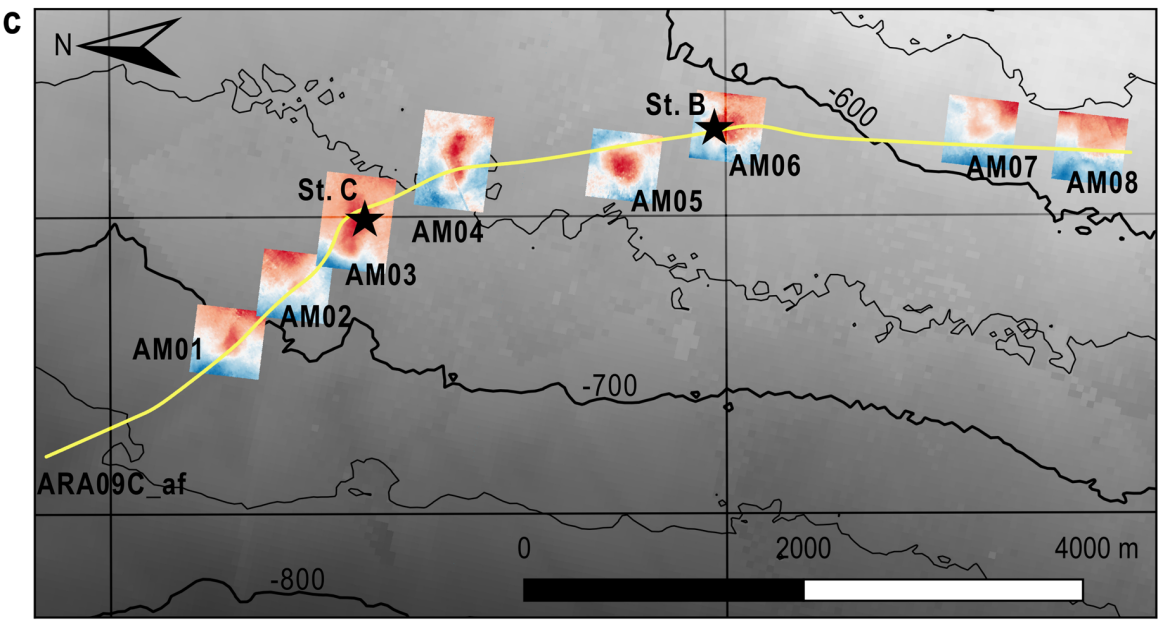

75.680

Figure 1. Map of study area. (a) Bathymetric map of Arctic Ocean. AO: Arctic Ocean, NS: Norwegian Sea, BaS: Barents Sea, GS: Greenland Sea, KS: Kara Sea, LS: Laptev Sea, ESS: East Siberian Sea, CS: Chukchi Sea, BeS: Beaufort Sea, and CP: Chukchi Plateau. (b) Simplified tectonic event map around the study area represented by red box (after Ilhan and Coakley, 2018). Two multichannel seismic lines are shown (gray: RV Langseth 11' (Dove et al., 2014; Ilhan and Coakley, 2018) and purple: RV Polarstern 08' (Hegewald and Jokat, 2013)). The blue dashed line is the inferred tectonic boundary between the North Chukchi Basin (NCB) and the Chukchi Plateau (CP). Star represents the marine heat flow stations in the Chukchi Abyssal Plain (CAP). Green circle represents location of the deep-sourced methane authigenic carbonate (Kolesnik et al., 2014). MR: Markov Ridge, NB: Northwind Basin, CB: Canada Basin, TB: Toll Basin. Bathymetry data is from the International Bathymetric Chart of the Arctic Ocean Version 3.0 (Jakobsson et al., 2012). (c) Expanded view of study area. The sub-bottom profile survey line of ARA09C_af is shown as yellow line and stations are marked as stars. Small rectangles named AM01-08 indicate the gas hydrate mound morphologies we found and their names. Colors in each rectangle, shallower in red and deeper in blue, are adjusted to reveal topography of the mounds. Bathymetry and contours are plotted based on Araon's multibeam echosounding survey results obtained during the ARA07C and -09C expeditions. 
In this study, we present for the first time recently acquired MBES and SBP data that characterize the surficial and sub-surficial acoustic characteristics of the gas hydrate mounds in the southwestern slope of the Chukchi Plateau in the Arctic Ocean. In addition, we discuss the formation of gas seepage and its activity using our observational data and previous studies. Our findings improve the current understanding of methane-related phenomena, particularly regarding the occurrence and distribution of gas hydrate mounds in the southwestern slope of the Chukchi Plateau.

\section{Background}

The southwestern slope of the Chukchi Plateau is located in the Arctic Ocean (International Hydrographic Organization, 1953; Jakobsson, 2002) and includes the tectonic boundary between the rifted North Chukchi Basin and continental fragment of the Chukchi Plateau (Grantz et al., 2011; Ilhan and Coakley, 2018; Fig. 1a and $b$ ).

The tectonic boundary, represented by the blue dashed line in Fig. $1 \mathrm{~b}$, can be inferred from the end of high free-air gravity anomalies and high magnetic anomalies toward the basin margin (Ilhan and Coakley, 2018). A recent seismic study has revealed unfolded sedimentary successions, approximately $4 \mathrm{~km}$ thick, from the Pre-Upper Jurassic to the present in the west of Chukchi Plateau (Butsenko et al., 2019). Deep-seated vertical faults reaching sediment succession below the Lower Cretaceous Unconformity have been previously identified in the southwestern slope of the Chukchi Plateau, close to our study area (Hegewald and Jokat, 2013; Ilhan and Coakley, 2018). The water depth deepens from its shallow borders in the Chukchi Plateau and shelf (approximately $500 \mathrm{~m}$ ) to $>2500 \mathrm{~m}$ in the Chukchi Abyssal Plain (Fig. 1b).

The MDAC with a low value of carbon isotope $\left(\delta^{13} \mathrm{C}=-63.6\right.$ to $-55.6 \%$ ) was found from the dredge site at $200 \mathrm{~m}$ water depth (Kolesnik et al., 2014), marked as a green circle in Figure 1b, close to the tectonic boundary. This supports the presence of potential oil and gas in the sedimentary succession (Kolesnik et al., 2014). Furthermore, the North Chukchi Basin is filled with $22 \mathrm{~km}$-thick sediments from the multiple rapid subsidence associated with rifting in favor of petroleum potential (Artyushkov, 2010).

Data from MBES and SBP surveys indicate widespread ice sheets and/or ice shelves extending to the Arctic Ocean during the Last Glacial Maximum (Jakobsson et al., 2014). Numerous glaciogenic features such as moraines, till wedges, and iceberg plough marks remain on the seafloor at water depths shallower than the shelf break of $\sim 580 \mathrm{~m}$ (Dove et al., 2014).

\section{Materials and Methods}

During the IBRV Araon expeditions ARA07C and -09C in 2016 and 2018, respectively, MBES and SBP surveys were carried out continuously and concurrently except during the station work for coring and heat flow measurement. The station sites were chosen based on the results of the two geophysical surveys. The MBES and SBP surveys on the IBRV Araon use a hull-mounted transmitter/ receiver operating as an integrated system (Kongsberg EM122 and its extension SBP120). The MBES survey uses a frequency of 12 $\mathrm{kHz}$ and a wide-beam angle of $90-120^{\circ}$. The SBP120 uses a frequency of $2.5-7 \mathrm{kHz}$ and a beam angle of $12^{\circ}$. The theoretical depth resolution is 5 to $15 \mathrm{~cm}$ at $1500 \mathrm{~m} / \mathrm{s}$ sound speed. Observation results are recorded in a conventional electronic format that can be post-processed for better images. The best resolution of the bathymetric map we processed was a square $10 \mathrm{~m}$ on a side.

The geothermal gradient in the seafloor sediments was determined by both the temperature readings at depths below the seafloor (Miniaturized Temperature Data Logger Type 1854, Antares Inc.; attached at several locations along the gravity corer barrel) and the vertical gradient of the gravity corer when penetrated into sediments (Data Storage Tag Tilt, Star Oddi Inc.). It is averaged based on the results of the two trials at each site. To compare the results, we visited both the abyssal plain (Station A in Fig. 1b as a control site; Table 1) and one of the mound morphologies (Station B in Fig. 1c; Table 1). In addition, the water temperature profile was obtained up to $33 \mathrm{~m}$ above the seafloor using conductivitytemperature-depth (CTD) castings at the same two stations. A water temperature corresponding to the depths of the geothermal gradient stations was assigned to their bottom water temperature (Table 1).

Sediment cores were retrieved using a $6 \mathrm{~m}$-long gravity corer, $2 \mathrm{t}$ in weight with $1.5 \mathrm{~m}$-long transparent liners inside the core barrel outfitted with a core catcher. Two sediment cores were retrieved from the mound morphologies with internal acoustic blanking (Stations $\mathrm{B}$ and $\mathrm{C}$ in Fig. 1c; Table 1). A visual inspection was performed onboard after a half split of the retrieved core.

Table 1. Details of gravity coring and heat flow measurements at the mounds containing gas hydrates

\begin{tabular}{|c|c|c|c|c|c|}
\hline $\begin{array}{l}\text { Station name in figures/ } \\
\text { Full name of the stations }\end{array}$ & $\begin{array}{l}\text { Latitude } \\
\left({ }^{\circ}\right)\end{array}$ & $\begin{array}{c}\text { Longitude } \\
\left({ }^{\circ} ;- \text { sign denotes west }\right)\end{array}$ & $\begin{array}{l}\text { Water depth } \\
\quad(\mathrm{m})\end{array}$ & $\begin{array}{l}\text { Core length } \\
\quad(\mathrm{cm})\end{array}$ & Remarks \\
\hline A/ARA09C01HFP & 76.5463 & -171.9219 & 2283 & NA & $\begin{array}{l}\text { Abyssal plain; same as Site } 03 \mathrm{M} 03 \text { (Wang et al., } \\
2013 \text { ); two trials of heat flow measurements; CTD* } \\
\text { casting lowered up to } 2250 \mathrm{~m} \text {. }\end{array}$ \\
\hline B/ARA07C13GVC2 & 75.6795 & -169.7379 & 610 & 235 & $\begin{array}{l}\text { AM06; occurrence of carbonates, gas hydrate, } \\
\text { shells, and odor (See Fig. 4) }\end{array}$ \\
\hline B/ARA09C09HFP & 75.6807 & -169.7366 & 619 & NA & $\begin{array}{l}\text { AM06; two trials of heat flow measurements; } \\
\text { CTD* lowered up to } 600 \mathrm{~m} .\end{array}$ \\
\hline C/ARA09C16GVC3 & 75.7034 & -169.7608 & 662 & NA & $\begin{array}{l}\text { AM03; occurrence of gas hydrate; Core length is not } \\
\text { determined because of significant expansion of void }\end{array}$ \\
\hline
\end{tabular}

*Conductivity-temperature-depth 

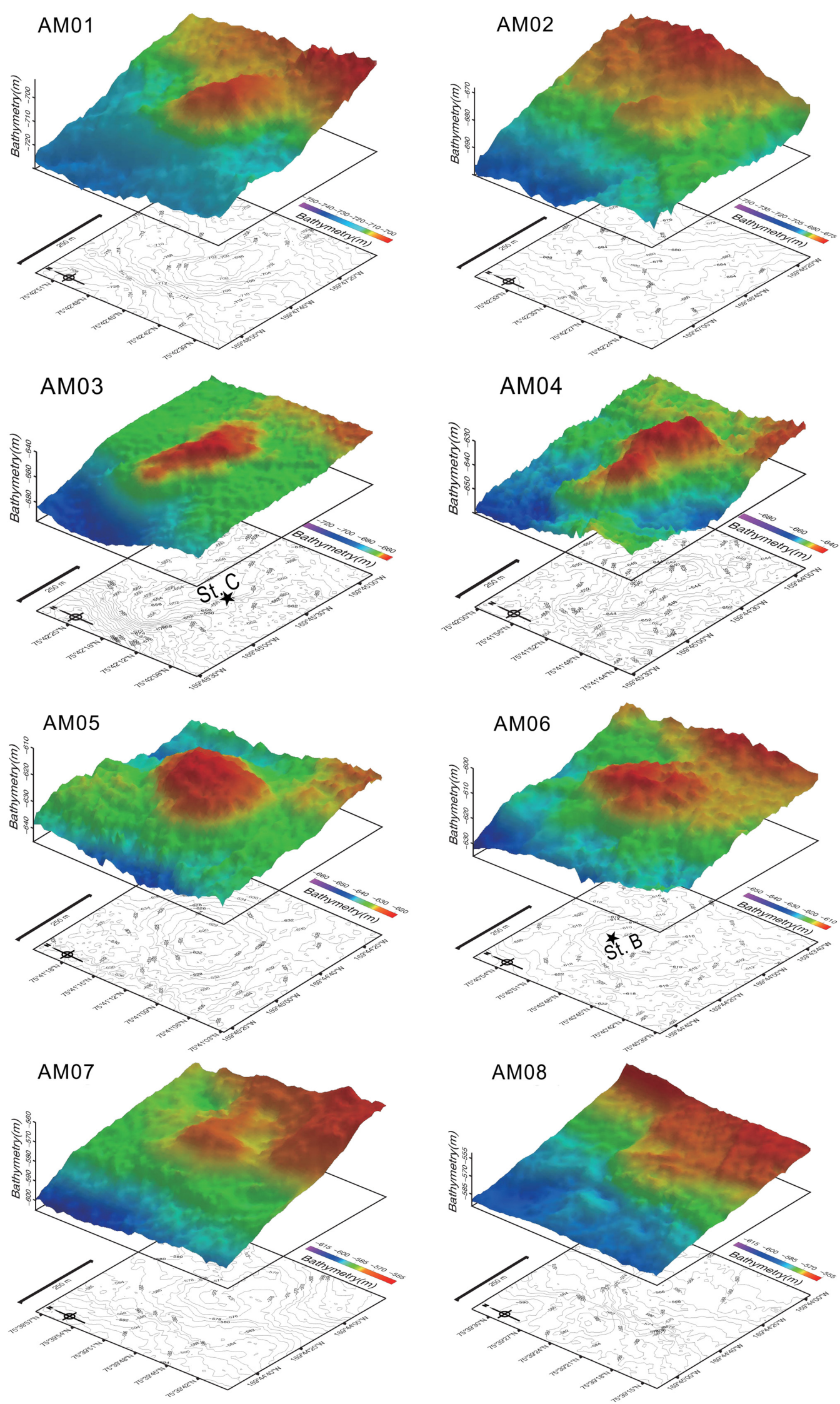

Figure 2. Multibeam bathymetry images from the perspective and plan views with contours of eight mound morphologies (AM01-08). An elongated or circular shape is identified with an extent of hundreds of meters in width and tens of meters in height. AM07 and -08 are not easily identifiable because of their smaller extent compared with surrounding glaciogenic features. See text for detail. All scale bars represent $250 \mathrm{~m}$ in length. 


\section{Results}

\section{Multibeam Echo Sounder}

The survey lines of the MBES were chosen to generate a high-resolution bathymetric map around the area where the mound morphologies occur in the southwestern slope of the Chukchi Plateau (Fig. $1 \mathrm{~b}$ and $\mathrm{c}$ ). To increase contrast between the mound morphologies and the seafloor, each rectangle in Fig. 1c is drawn based on depth variation within the rectangle area and the topographic high is represented by the red color. We identified eight mound morphologies (Araon Mound 01 to 08 in Fig. 1c) using joint analysis with the SBP results. The mound morphologies were seen in water depth intervals of 580-780 m, corresponding to the upper slope. Their spatial distribution is sub-linear in the map view with several hundred meters interval. Wiggles of bathymetric contours stem from rough smoothing of water depths acquired by the MBES survey.

A close look at the surface bathymetry of each mound morphology provides regular patterns in morphology. They have a generally circular or elongated shape in the map view, with diameters ranging from tens of meters to approximately $400 \mathrm{~m}$ and a height up to $20 \mathrm{~m}$
(Fig. 2). Due to low height of the morphology, it is not easily identified when locating the inclined bathymetry. For instance, AM02, 07, and -08 are not clearly visible in the MBES survey result. In such a case, acoustic characteristics below the seafloor of the morphology are used for identification (Fig. 3). Shape of the crest is generally convex upward containing a single peak at the center of the morphology except for AM04. A detailed contour of AM04 showed three peaks shallower than $638 \mathrm{~m}$.

At AM03 and -06, those that have a peak spreading over a moderately larger area are chosen for coring sites (Stations B and C represented as stars in Fig. 2) because flattened top morphology is often formed by prolonged fluid-mud efflux in the cases of other gas seepage structures (e.g., Bohrmann et al., 2003; Perez-Garcia et al., 2009; Paull et al., 2015b).

\section{Sub-bottom Profiler}

Acoustic characteristics below the seafloor across the mound morphologies were observed from the SBP data of ARA09C af (Figs. 1c and 3). Acoustic blanking, characterized by massive top and transparent downward (orange areas in Fig. 3b) is observed vertically below the mound morphologies, marked by triangles in Fig. $3 \mathrm{a}$.

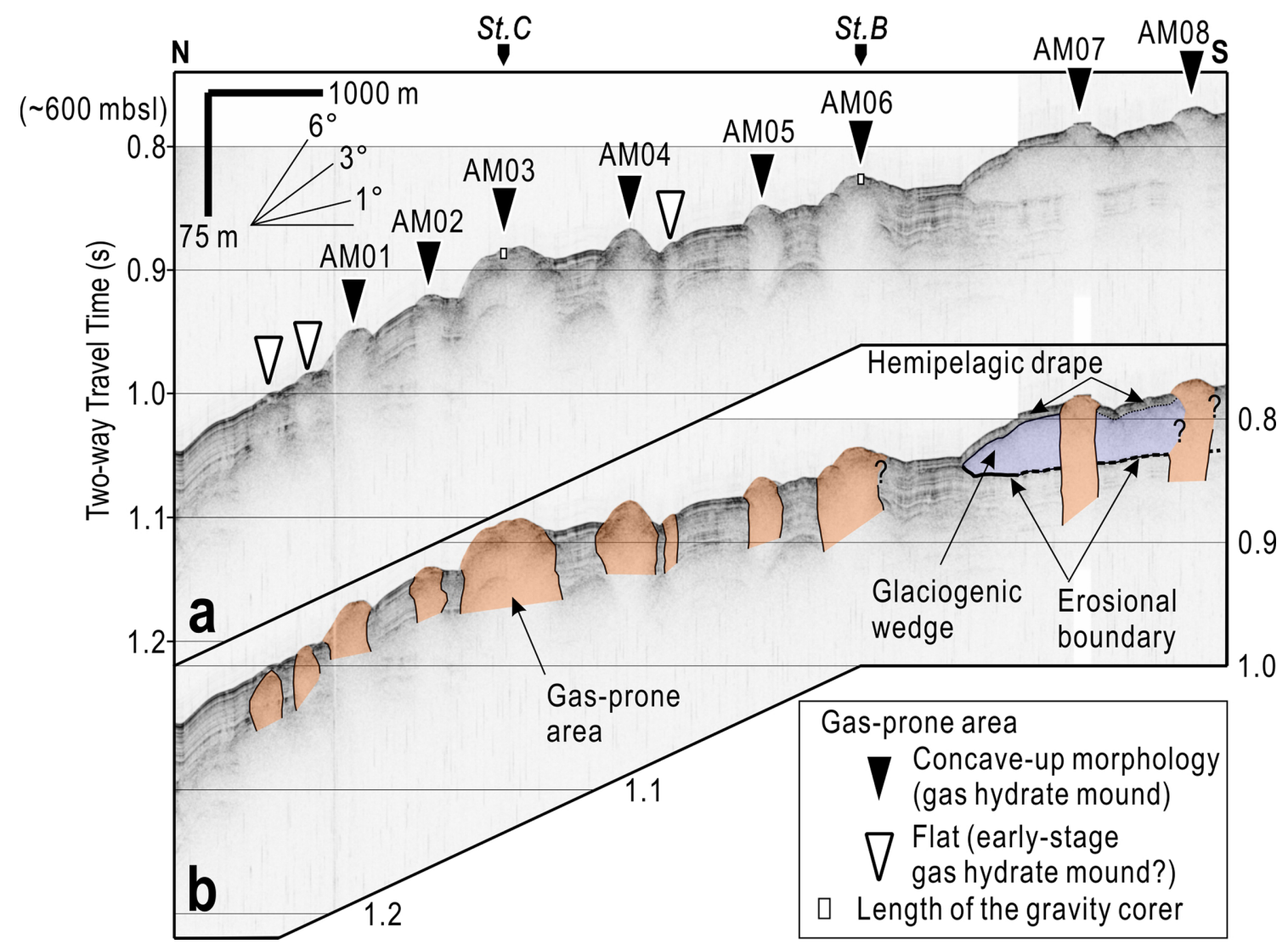

Figure 3. Sub-bottom profile image (a) which runs across the mound morphologies (triangles) and its interpretation (b). Mound morphologies with acoustic blanking below the seafloor (orange area in b) are distinguished from the normal seafloor with flat-lying layers. They can be classified into two types based on whether it has a distinct surface manifestation with/without positive topography, represented by black triangles with a name and white triangles, respectively. Acoustic blanking is shown vertically from the mound morphologies with lateral sharp boundaries in most cases. A rather flattened top occurs in AM03 and -06 while a concave-upward shape with one peak is present in the other Araon Mounds. Gas hydrate is retrieved using a gravity corer whose length is plotted as a white rectangle at Stations B (AM06) and C (AM03). AM07 and -08 are located in glaciogenic wedge (purple area in b). Slope inclination of the mound morphologies is generally less than $6^{\circ}$. 
In some cases, despite the acoustic blanking below, positive topographic manifestation is negligible (white triangles). It is notable that the leftmost white triangle shows surficial flat-lying layer above acoustic blanking. On the other hand, Araon Mounds (black triangles) have significant positive manifestation. Surfaces of AM03 and -06 with rather flattened top are irregular and not as smooth as the other mounds.

Outside of the mound morphologies, continuous and seafloor-parallel flat-lying layers suggesting hemipelagic sedimentation are observed (e.g., Dove et al., 2014). The lateral boundary of the acoustic blanking with hemipelagic sediments is generally sharp and with crosscutting geometries (Fig. 3b). However, faults are not identified in the margins of the mound morphologies. The boundary continues to $\sim 75 \mathrm{~m}$ below the seafloor in the case of AM07 although its vertical continuity could not be examined due to penetrating depth limit of the SBP survey in the study area.

The mound morphologies occasionally occur above the acoustic feature having transparent and homogeneous characteristics with a sharp lower boundary (area marked by purple in Fig. 3b) as in the cases of AM07 and -08. The purple area is interpreted as till wedge, one of the common glaciogenic features in the study area, based on the evidence of its contact with lower layers and its location close to the shelf edge (Dove et al., 2014). Acoustic blanking continues to the surface at AM07 and -08 while flat-lying sediment layers are identified over the till wedge outside of the mound morphologies.

Gas flares in the water column were not observed in the study area during the ARA07C and -09C expeditions by either the SBP or the single beam echo sounder. These are frequently revealed in vigorously active seeping areas such as the Sakhalin continental slope (Jin et al., 2011; Kim et al., 2013b).

\section{Coring}

Sediment cores are retrieved from Stations B and C at AM06 and -03 , respectively (rectangles for location and length of the gravity corer in Fig. 3a). A 2.3 m-long sediment core containing gas hydrate, in situ carbonate, and shells was retrieved from Station B at AM06 (Fig. 4). A vein-shape gas hydrate was collected in the core catcher, at the bottom of the sediment core (star marks in Fig. 4). In addition, a massive layer of gas hydrate was also found at Station $\mathrm{C}$ at AM03 (Fig. 2a and inset of Fig. 4). These are strong evidences that prove occurrence of gas-rich fluid in the mound morphologies. The gas composition revealed to consist mainly of methane (Kim et al., 2017; Kim et al., 2020).

In addition, there are in situ carbonates at several horizons (square marks in Fig. 4) mostly in the sedimentary section of the gray-dominant layer (G in Fig. 4) alternating with brown-dominant layers (B in Fig. 4). The occurrence of in situ carbonates and gas hydrate is observed in the gray-dominant layer. In situ carbonates have various shapes and sizes but have similar porous surfaces.

\section{Geothermal Gradient}

The temperature at depths below the seafloor was collected from two different stations, Station A for the abyssal plain and Station B for the mound morphologies, to reveal the thermal conditions of each location (Figs. 1b, c, and 5; Table 2). Station A is located at a depth of $2283 \mathrm{~m}$ and belongs to the abyssal plain, where continuous horizontal sedimentary layers without faults or irregular morphologies occur. In contrast, Station B is located on one of the mound morphologies, AM06, where acoustic blanking occurs below (Fig. 3). The resemblance of the results of the two trials at each station strongly indicates a good reliability of the observations (Fig. 5).

In the abyssal plain (Station A), geothermal gradients of $56.5 \mathrm{mK} /$ $\mathrm{m}$ with good linearity are estimated, representing normal seafloor conditions without any thermal disturbances by either advective fluids in the sediments or annual changes in bottom water temperature (lighter signs in Fig. 5; Table 2). This station is the same as Station $03 \mathrm{M} 03$ in a recent paleoceanographic study (Wang et al., 2013) that revealed high sedimentation rates (up to $8 \mathrm{~cm} / \mathrm{kyr}$ ) during MIS 3, corresponding roughly to the topmost $3 \mathrm{~m}$ of the sediment section. However, the sedimentation effect did not seem to be imprinted in

Table 2. Observed geothermal gradients from the abyssal plain and gas hydrate mound

\begin{tabular}{|c|c|c|c|c|c|c|c|c|}
\hline \multirow{4}{*}{$\begin{array}{c} \\
\text { Tilt }^{* 1} \\
\text { No. }\end{array}$} & \multicolumn{4}{|c|}{ Station A (abyssal plain; control site) } & \multicolumn{4}{|c|}{ Station B (AM06) } \\
\hline & \multicolumn{2}{|c|}{ Trial \#1 } & \multicolumn{2}{|c|}{ Trial \#2 } & \multicolumn{2}{|c|}{ Trial \#1 } & \multicolumn{2}{|c|}{ Trial \#2 } \\
\hline & \multicolumn{2}{|c|}{81} & \multicolumn{2}{|c|}{81} & \multicolumn{2}{|c|}{76} & \multicolumn{2}{|c|}{82} \\
\hline & $\operatorname{Depth}^{* 2}(\mathrm{~m})$ & Temp. $\left({ }^{\circ} \mathrm{C}\right)$ & $\operatorname{Depth}^{* 2}(\mathrm{~m})$ & Temp. $\left({ }^{\circ} \mathrm{C}\right)$ & $\operatorname{Depth}^{* 2}(\mathrm{~m})$ & Temp. $\left({ }^{\circ} \mathrm{C}\right)$ & $\operatorname{Depth}^{* 2}(\mathrm{~m})$ & Temp. $\left({ }^{\circ} \mathrm{C}\right)$ \\
\hline 1 & 0.000 & -0.240 & 0.000 & -0.238 & 0.000 & NA & 0.000 & NA \\
\hline 2 & 0.911 & NA & 0.913 & -0.174 & 0.083 & 0.988 & 0.847 & 0.979 \\
\hline 3 & 1.570 & -0.157 & 1.575 & -0.143 & 1.784 & 0.933 & 1.821 & 0.897 \\
\hline 4 & 3.512 & -0.041 & 3.521 & -0.034 & 3.011 & 0.875 & 3.073 & 0.873 \\
\hline 5 & 4.204 & -0.009 & 4.034 & -0.003 & 3.298 & 0.870 & 3.366 & 0.866 \\
\hline 6 & 4.540 & 0.016 & 4.552 & 0.021 & NA & NA & NA & NA \\
\hline 7 & 5.061 & 0.043 & 5.074 & 0.053 & NA & NA & NA & NA \\
\hline Est. GG & \multicolumn{2}{|c|}{$56.8\left(\mathrm{R}^{2}=0.9992\right)$} & \multicolumn{2}{|c|}{$56.2\left(\mathrm{R}^{2}=0.9987\right)$} & \multicolumn{2}{|c|}{$-48.5\left(\mathrm{R}^{2}=0.9913\right)$} & \multicolumn{2}{|c|}{$-41.8\left(\mathrm{R}^{2}=0.8797\right)$} \\
\hline Aver. $\mathrm{GG}^{* 4}$ & \multicolumn{4}{|c|}{56.5} & \multicolumn{4}{|c|}{-45.2} \\
\hline
\end{tabular}

${ }^{* 1}$ Inclined angle with respect to a horizontal plane when the corer is penetrated into the sediments. 90 for vertical.

${ }^{*}$ Vertical distance from the topmost sensor. It is calculated based on both distance from the thermistors attached along the corer barrel and the tilt.

${ }^{*}$ Estimated geothermal gradient.

${ }^{* 4}$ Averaged geothermal gradient. 


\section{St. B}

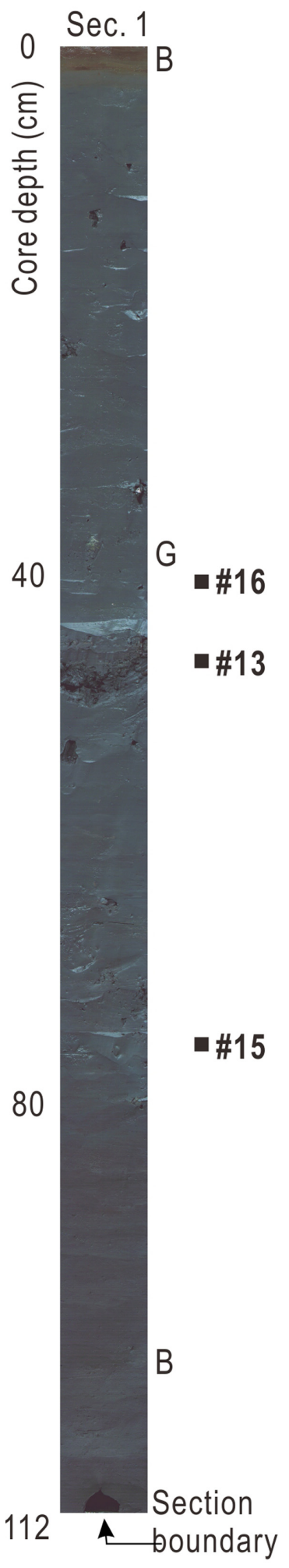

Authigenic carbonate

$\star$ Gas hydrate
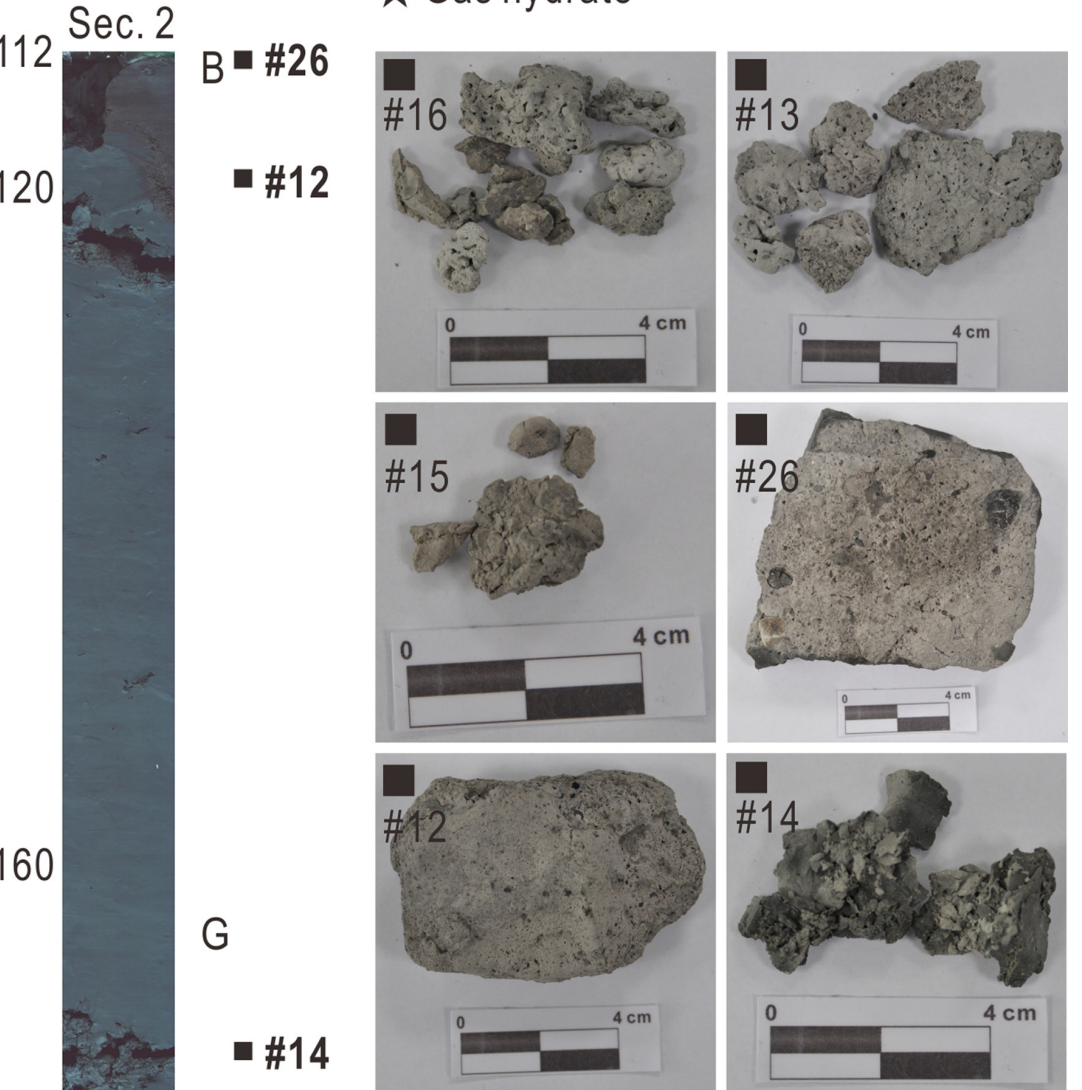

- \#14
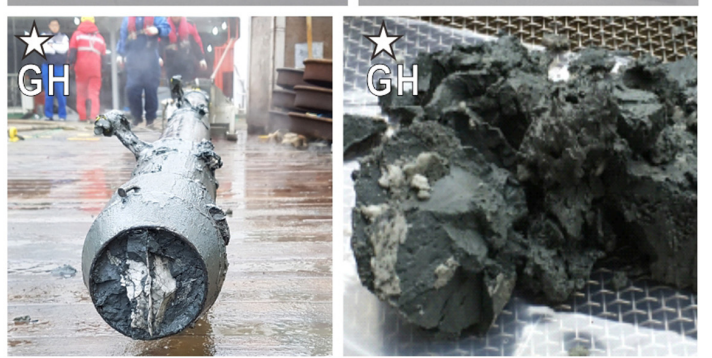

200

\section{St . C}
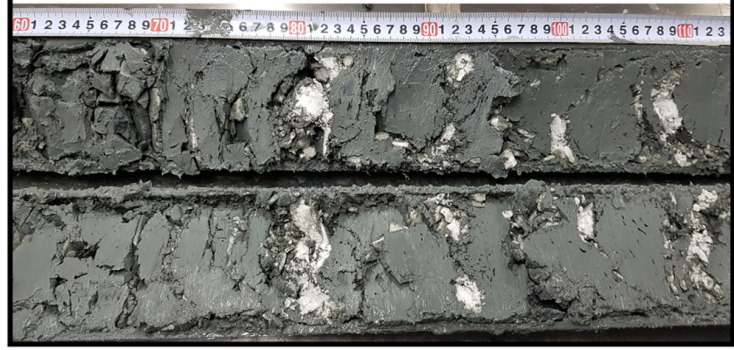

235

Figure 4. Sediment core retrieved from Station B and a part of the embedded gas hydrate from Station C (inset). Core depth of the authigenic carbonates and methane hydrate are shown with an optical image of split sediment core from Station B. Authigenic carbonates occur in several different horizons. In the inset, the interval between the red ticks of the ruler is $10 \mathrm{~cm}$. 


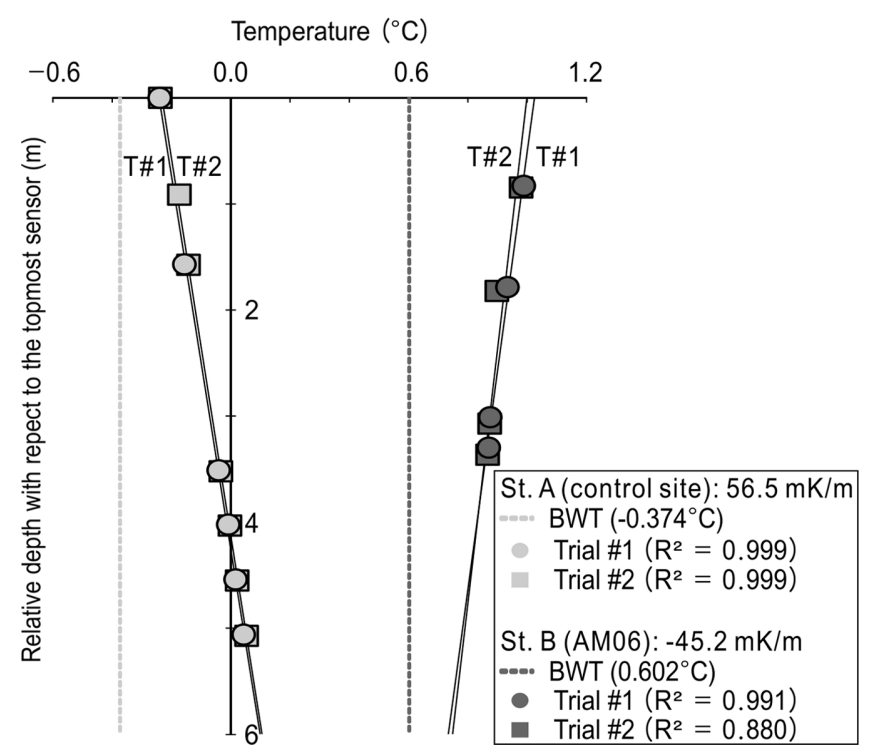

Figure 5. Comparison of heat flow measurement results between Stations $A$ (the abyssal plain; control site) and B (AM06). The negative geothermal gradient of the gas hydrate mound is in contrast with the positive one of the abyssal plain. Bottom water temperatures (BWT) at the two stations are indicated by vertical dashed lines.

the geothermal gradient. In marked contrast, negative geothermal gradients of $-45.2 \mathrm{mK} / \mathrm{m}$ are estimated from AM06 (Station B; darker signs in Fig. 5; Table 2), indicating that the thermal conditions were significantly disturbed.

In addition, all temperature readings with depth from the two sites were higher than the bottom water temperature at each site (dashed lines in Fig. 5). The bottom water temperature was acquired by casting of the CTD profiler at Stations A and B (Table 1). Together with the geothermal gradient, it is an essential parameter to estimate the base of the gas hydrate stability zone using the known pressuretemperature relationship of gas hydrate stability (Sloan Jr. and Koh, 2007).

\section{Discussion}

\section{Mound Morphologies Interpreted as Gas Hydrate Mounds}

Gas hydrate mounds, also known as pingoes, are a common feature identified in geophysical surveys in gas hydrate areas (e.g., Sassen et al., 1999; Paull et al., 2008; Freire et al., 2011; Serié et al., 2012; Somoza et al., 2014; Hong et al., 2017). They generally show a positive topographic expression extending up to a few hundred meters in length and a few tens of meters in height. Chemosynthetic communities and gas vents are frequently found on their surfaces (e.g., de Beer et al., 2006; Paull et al., 2015b). Instances of vertical acoustic blanking below the mound, interpreted as a gas chimney, are often identified from seismic and SBP data (Loncke et al., 2004; Jin et al., 2011).

Geophysical and geological observations provide the origin of the mound morphologies in the southwestern slope of the Chukchi Plateau. Despite the large diameter and shorter height in the map view, the cone/dome shape of mound morphologies is a characteristic feature that distinguishes them from both erosional and depositional structures on the seafloor. Although the scale varies with location (Figs. $3 \mathrm{a}$ and $\mathrm{b}$ ), the study herein only discovered convex-upward topography, implying an extruded or built-up origin. Particularly, the three peaks at AM04 and rather flattened tops of AM03 and -06 are explained well in this manner.

Acoustic blanking can be generated by instrumental or operational errors due to fast ship speeds and steep angles of the slope compared to given ping rate of the SBP survey, instead of geological reasons such as stiff top material above blanking zone or gascharged sediments (Sancier, 1971). In the study area, most spots with acoustic blanking below them (triangles in Fig. 3a) have less than $6^{\circ}$ in surface inclination. Moreover, the blanking is found even below the flattened tops of AM03 and -06. Flat-lying layers above the blanking (the leftmost white triangle) also occur. These findings indicate that the acoustic blanking we observed has acoustic characteristics based on geological reasons and are not associated with instrumentation errors.

Hence, we argue that the acoustic blanking zone below the mound morphology might indicate gas-charged sediments (e.g., Hovland and Curzi, 1989; Bouriak and Akhmetjanov, 1998; Roberts, 2001; Paull et al., 2015a). The sharp boundary of the zone to the outside and the lack of signs of faults suggest a focused flow of gas, i.e., a gas chimney (Jin et al., 2011), which disrupted the welldeveloped horizontal reflector once (e.g., Paull et al., 2015a). Small amounts of free gas, only $1-2 \%$ by volume, can cause this acoustic signature (McQuillin et al., 1984). The semi-transparent echo character without visible layers is restricted in the morphology and may represent seabed reflector impeding the penetration of acoustic signals than in the surroundings, particularly in the smaller mound morphologies represented by white triangles in Fig. 2a (García-García et al., 2004).

The vein-shape gas hydrate and authigenic carbonates occur at the bottom of a sediment core retrieved using the gravity corer (marked as GH in Fig. 4). The gas hydrate is strong evidence for the presence of methane-rich fluid below. Gas hydrate generally forms where there is enough gas and water under stable pressure and temperature conditions, referred as the gas hydrate stability zone (Sloan Jr. and Koh, 2007). While the sediment core from Station B at AM06 shows lithology of the alternating brown and grayish-dominant layers that seems to be comparable to one from an abyssal plain (Wang et al., 2012), we do not have the exact correlation information yet.

As of now, evidence for the past or current presence of a chemosynthetic community is not clearly found from the cores. Such communities frequently thrive in the active seeping areas in the Arctic Ocean (e.g., de Beer et al., 2006; Paull et al., 2015b). In fact, intact or broken bivalves also occur in the upper gray-dominant layer but detailed taxonomic identification, age dating, and analyses of carbon and oxygen isotopes, which could provide detailed age, stratigraphic information, and occurrence of chemosynthetic community (e.g., Ambrose Jr. et al., 2015), remain to be carried out.

As described herein, the multiple pieces of evidence indicate that the discovered mound morphologies have an origin related to an upward migration of gas-rich fluid flow via a gas chimney. In addition, nei- 
ther mud efflux from the mound top, representative feature of a mud volcano (Mazzini and Etiope, 2017), nor depressed topography around the mound like the pingo-like feature (Paull et al., 2007) is not identified from the dataset. Therefore, at this stage, it is concluded that the mound morphologies are distinguished as gas hydrate mounds. Recent studies postulated that such flow might result in both hydrate growth and precipitation of MDAC at subsurface causing the domeshaped topography by either expansion of sediment volume or positive buoyancy (Serié et al., 2012; Somoza et al., 2014; Waage et al., 2019). Particularly, this study documenting the Araon Mounds in terms of geophysical and geological observations, is the first comprehensive case study to describe the occurrence of gas hydrate mounds in the Central Arctic Ocean.

\section{Seeping Activity of Gas Hydrate Mounds}

The seeping activity of the Araon Mounds was not directly measured during the two expeditions. Nevertheless, we attempt to deduce it based on indirect geological and geophysical evidence. The geothermal gradient observed in the subsurface seafloor can be used as a proxy for depicting thermal effects caused by environmental conditions (Davis et al., 1999; Hamamoto et al., 2005). The negative geothermal gradient from the AM06 (Station B in Fig.5) is caused by a transient thermal effect, due to either an annual change in the bottom water temperature or the conductive fluid within sediments (Géli et al., 2001). The water temperature at intermediate depths in the western Arctic seas is modulated by the Atlantic water input and its distribution (Dmitrenko et al., 2010). However, a transient effect of bottom water temperature change, which produces a sinusoidal temperature-depth curve, is not observed in the result from Station B, even though the observed bottom water temperature was colder than the sediment temperature below the seafloor. In that regard, the negative geothermal gradient stems from fluid convection within sediments (e.g., Feseker et al., 2009; Machiyama et al., 2009; Chang et al., 2010). The location of Station B, on the rim of the gas hydrate mound (Fig. 2), also makes fluid convection within sediments more plausible because flux from the deep generally decreases with depth as the observation site situates farther from the conduit axis (e.g., Feseker et al., 2008). Hence, we argue that the negative geothermal gradient at AM06 (Station B) is caused by active present-day seepage.

One could argue that the lack of signs of gas flares in the water column in this study area indicates present inactivity. However, it is noteworthy that methane is mainly dispersed as a form of methanerich fluid within the sediment, if the methane concentration is low enough to dissolve (Xu and Ruppel, 1999). The finding that acoustic gas flares were not detected, even when the gas hydrate mound was impacted by the gravity corer, also supports the fact that there was rarely free gas in the mound, at least presently. This is not inconsistent with acoustic blanking in the mound, which was generated by a small amount of free gas 1-2\% in volume (McQuillin et al., 1984). Besides supply of low concentration of methane from deep, the low methane concentration at the subsurface depth of the gas hydrate mound could be accomplished by activity of methane-oxidizing microbes (Boetius et al., 2000; Boetius and Wenzhöfer, 2013).

In addition, it is known that authigenic carbonate plays a role in indicating the location of an oxic/anoxic boundary in the past (Peck- mann et al., 2001) and was controlled by an upward methane-rich fluid flux (Feng et al., 2010). In the retrieved core, different horizons of authigenic carbonates were identified, presumably suggesting some periodicity in the methane-rich fluid flux with geologic time. Timing of methane efflux can be further evaluated by age dating of authigenic carbonates. In case of the Norwegian and Svalbard margin where extensive ice sheets have occurred during glacial periods like the study area, methane emission is considered to continue for an order of $10 \mathrm{kyrs}$ starting coincidently with deglaciation causing pressure release related to the retreat of ice sheet (Crémière et al., 2016; Himmler et al., 2019).

It can be summed up that there was prolonged methane-rich fluid flux at the gas hydrate mounds, at least at AM06 in the study area and that presently the fluid still flows through the mound from deep, indicating an active seepage.

\section{Possible Origin and Distribution of Gas Hydrate Mounds}

The geochemical signature of the gas from methane hydrate and porewater suggests its formation origin (Sloan Jr. and Koh, 2007). At AM06, methane collected from pore water, headspace gas, and dissociated gas hydrate in a sediment core was classified into thermogenic methane based on a carbon and hydrogen isotope plot (Kim et al., 2017; Kim et al., 2020). Although the study used a small sample of data, it might indicate that the methane in this gas hydrate mound originated from deeper areas where thermogenic process prevails and then migrated into shallower depths. Using the CAGEHYD program (Vadakkepuliyambatta, 2019), the base of gas hydrate stability zone is estimated to be as shallow as $164 \mathrm{~m}$ below the seafloor, based on given bottom water temperature at AM06, geothermal gradient at Station A, and assumption of pure methane.

Vertical faults play an important role as a pathway for fluid migration (e.g., Boles et al., 2004). Studies regarding the deep sedimentary structure in the study area are sparse, however, two expeditions collecting multichannel seismic profiles (shown as purple and gray lines in Fig. $1 \mathrm{~b}$ and c) close to the study area were documented by Hegewald and Jokat (2013), Dove et al. (2014), and Ilhan and Coakley (2018). Although faults reaching to the seafloor are not identified, their frequent occurrence in the vicinity of the shelf edge is noteworthy. Some faults reach up to approximately $3 \mathrm{~s}$ in two-way travel time below the seafloor (Hegewald and Jokat, 2013). This provides an implication for the presence of deep-seated faults as a vertical pathway for methane-rich fluid from deeper to shallow depths (Serié et al., 2012; Waage et al., 2019).

The occurrence of the Araon Mounds is restricted to a depth interval of 580-780 $\mathrm{m}$ in the southwestern slope of the Chukchi Plateau. This is partly because of the small coverage of our survey area, and/ or partly due to the fault-controlled pathway of methane-rich fluid. The study area is located close to an assumed tectonic boundary between the Chukchi Basin, Chukchi Plateau, and the Northern Chukchi Basin (blue dashed line in Fig. 1b; Ilhan and Coakley, 2018). According to a previous study, the northern boundary of the North Chukchi Basin, which was formed by rifting and is currently occupied by sediments in the Chukchi Shelf, is postulated to be based on a free-air gravity anomaly and a magnetic anomaly (Fig. 1b). In general, faults commonly develop along the basin margin of the rifted basin (e.g., Rob- 
erts and Yielding, 1991; Fossen and Rotevatn, 2016). We speculate that the occurrence and distribution of the discovered gas hydrate mound are related to faults that serve as a migration pathway. Moreover, in the context of the fault-related plumbing systems underlying the gas hydrate mound, there is the possibility that a chain of gas hydrate mounds is located in the basin along the basin-marginal fault marked as the blue dashed line in Fig. 1b. If so, the gas hydrate mounds in the vicinity of the basin margin can serve as a surface manifestation of the bounding faults. In the same context, a site of authigenic carbonate indicating an upward migration of methanerich fluid from the deep (represented as a green circle in Fig. 1b; Kolesnik et al., 2014) in the vicinity of the basin-marginal fault also supports our argument.

The finding that the gas hydrate mounds occur at depths generally deeper than those affected by glaciogenic events in the western Arctic raises a question about the timing of the formation of gas hydrate mounds. While methane emission timing and duration in the other Arctic margins count on the onset of ice sheet retreat since the Last Glacial Maximum (Jakobsson et al., 2014), this cannot be tested in the study area unless proper age data is available. For instance, the age of glaciogenic till wedge underlain by the AM07 and -08 (Fig. 3) as well as the stratigraphic information from the retrieved core from the AM06 would be vital to conclude the timing.

\section{Conclusions}

We present initial evidence for the occurrence and the possible origin of the gas hydrate mound in the southwestern slope of the Chukchi Plateau, Arctic Ocean. Based on high-resolution MBES and SBP data, we identified eight cone/dome-shaped mound morphologies, each a few hundred meters in diameter and up to a few tens of meters in height. The convex-up shapes and gas-prone area found below the morphologies indicate that the morphologies are related with focused vertical gas-rich fluid flow from the deep. The gas hydrate sample from the mounds and previous results about the isotope signature of the methane obtained from the core, support an upward migration of methane-rich fluid from the deep. Considering lack of both mud efflux from the top unlike in mud volcanos and moat around the mound unlike in pingo-like features, the mound morphologies we found can be classified as gas hydrate mounds (pingoes) and we have named them as the Araon Mounds. The negative geothermal gradient of the mound supports that methane-rich fluid actively flows through it at present. In addition, past methane-rich fluid flux is considered to fluctuate on the basis of different horizons of authigenic carbonate in the retrieved core form the mound. Given the identified deep-seated faults in the vicinity of the study area (possibly related to a rifted basin margin of the North Chukchi Basin with respect to the Chukchi Plateau), the methane-rich fluid flux seems to migrate vertically along the faults bounding the North Chuckchi Basin. If so, the gas hydrate mounds discovered to the southeast of the study area serve as surface manifestations of the bounding faults. However, at this stage, there are many uncertainties that requires further clarification, i.e., timing of mound formation, associated biological processes, and quantification of the seeping activity.

\section{Acknowledgements}

We would like to thank the scientific team of the ARA07C and ARA09C expeditions, and the captain and crew of the IBRV Araon for their help in collecting data. This research was supported by the KIMST Grant 20160247. Y.-G. Kim was also supported by the KMA Research and Development Program (KMI2018-02110), the Basic Science Research Program through the National Research Foundation of Korea (NRF) funded by the Ministry of Education (No. 2019R1A6A1A03033167), and the Young Researcher Program through the NRF grant funded by the Korea government (MSIT) (No. 2020R1C1C1007495). Authors appreciate the two anonymous reviewers for their critical and valuable comments that helped to improve the manuscript.

\section{References}

Ambrose Jr., W.G., Panieri, G., Schneider, A., Plaza-Faverola, A., Carroll, M.L., Åström, E.K.L., Locke V.W.L., and Carroll, J., 2015, Bivalve shell horizons in seafloor pockmarks of the last glacial-interglacial transition: a thousand years of methane emissions in the Arctic Ocean, Geochemistry, Geophysics, Geosystems, v. 16, pp. 4108-4129.

Andreassen, K., Hart, P.E., and Grantz, A., 1995, Seismic studies of a bottom simulating reflection related to gas hydrate beneath the continental margin of the Beaufort Sea, Journal of Geophysical Research: Solid Earth, v. 100, pp. 12659-12673.

Artyushkov, E.V., 2010, The superdeep North Chukchi Basin: formation by eclogitization of continental lower crust, with petroleum potential implications, Russian Geology and Geophysics, v. 51, pp. 48-57.

Boetius, A., Ravenschlag, K., Schubert, C.J., Rickert, D., Widdel, F., Gieseke, A., Amann, R., Jørgensen, B.B., Witte, U., and Pfannkuche, O., 2000, A marine microbial consortium apparently mediating anaerobic oxidation of methane, Nature, v. 407, pp. 623-626.

Boetius, A., and Wenzhöfer, F., 2013, Seafloor oxygen consumption fuelled by methane from cold seeps, Nature Geoscience, v. 6, pp. 725.

Bohrmann, G., Ivanov, M., Foucher, J.P., Spiess, V., Bialas, J., Greinert, J., Weinrebe, W., Abegg, F., Aloisi, G., Artemov, Y., Blinova, V., Drews, M., Heidersdorf, F., Krabbenhöft, A., Klaucke, I., Krastel, S., Leder, T., Polikarpov, I., Saburova, M., Schmale, O., Seifert, R., Volkonskaya, A., and Zillmer, M., 2003, Mud volcanoes and gas hydrates in the Black Sea: new data from Dvurechenskii and Odessa mud volcanoes, GeoMarine Letters, v. 23, pp. 239-249.

Boles, J.R., Eichhubl, P., Garven, G., and Chen, J., 2004, Evolution of a hydrocarbon migration pathway along basin-bounding faults: Evidence from fault cement, AAPG Bulletin, v. 88, pp. 947-970.

Bouriak, S.V., and Akhmetjanov, A.M., 1998, Origin of gas hydrate accumulations on the continental slope of the Crimea from geophysical studies, Geological Society, London, Special Publications, v. 137, pp. 215-222.

Butsenko, V.V., Firsov, Y.G., Kashubin, S.P., Piskarev, A.L., and Zholondz, S.M., 2019, Chukchi Plateau and Chukchi Basin, in Piskarev, A., Poselov, V., and Kaminsky, V., Geologic Structures of the Arctic Basin, Springer International Publishing, pp. 269-280.

Chang, H.T., Shyu, C.T., Chang, H.I., Tsao, S., and Chen, C.X., 2010, Geothermal monitoring of Kueishantao iland offshore of northeastern Taiwan, Terrestrial, Atmospheric Oceanic Sciences, v. 21, pp. 563-573.

Collett, T., and Dallimore, S., 2003, Permafrost-Associated Gas Hydrate, in Max, M., ed., Natural Gas Hydrate, v 5, Springer Netherlands, pp. 43-60.

Crémière, A., Lepland, A., Chand, S., Sahy, D., Condon, D. J., Noble, S. R., Martma, T., Thorsnes, T., Sauer, S., and Brunstad, H., 2016, Timescales of methane seepage on the Norwegian margin following collapse of the 
Scandinavian Ice Sheet, Nature Communications, v. 7, pp. 11509.

Davis, E. E., Chapman, D. S., Wang, K., Villinger, H., Fisher, A. T., Robinson, S. W., Grigel, J., Pribnow, D., Stein, J., and Becker, K., 1999, Regional heat flow variations across the sedimented Juan de Fuca Ridge eastern flank: Constraints on lithospheric cooling and lateral hydrothermal heat transport, Journal of Geophysical Research, Solid Earth, v. 104, pp. $17675-17688$.

de Beer, D., Sauter, E., Niemann, H., Kaul, N., Foucher, J.-P., Witte, U., Schlüter, M., and Boetius, A., 2006, In situ fluxes and zonation of microbial activity in surface sediments of the Håkon Mosby Mud Volcano, Limnology and Oceanography, v. 51, pp. 1315-1331.

Dmitrenko, I. A., Kirillov, S. A., Tremblay, L. B., Bauch, D., Hölemann, J. A., Krumpen, T., Kassens, H., Wegner, C., Heinemann, G., and Schröder, D., 2010, Impact of the Arctic Ocean Atlantic water layer on Siberian shelf hydrography, Journal of Geophysical Research, Oceans, v. 115, http://doi.org/10.1029/2009JC006020

Dove, D., Polyak, L., and Coakley, B., 2014, Widespread, multi-source glacial erosion on the Chukchi margin, Arctic Ocean, Quaternary Science Reviews, v. 92, pp. 112-122.

Feng, D., Chen, D., Peckmann, J., and Bohrmann, G., 2010, Authigenic carbonates from methane seeps of the northern Congo fan: Microbial formation mechanism, Marine and Petroleum Geology, v. 27, pp. 748756.

Feseker, T., Foucher, J.P., and Harmegnies, F., 2008, Fluid flow or mud eruptions? Sediment temperature distributions on Håkon Mosby mud volcano, SW Barents Sea slope: Marine Geology, v. 247, pp. 194-207.

Feseker, T., Pape, T., Wallmann, K., Klapp, S. A., Schmidt-Schierhorn, F., and Bohrmann, G., 2009, The thermal structure of the Dvurechenskii mud volcano and its implications for gas hydrate stability and eruption dynamics: Marine and Petroleum Geology, v. 26, pp. 1812-1823.

Fossen, H., and Rotevatn, A., 2016, Fault linkage and relay structures in extensional settings-A review, Earth-Science Reviews, v. 154, pp. 14-28.

Freire, A.F.M., Matsumoto, R., and Santos, L.A., 2011, Structural-stratigraphic control on the Umitaka Spur gas hydrates of Joetsu Basin in the eastern margin of Japan Sea, Marine and Petroleum Geology, v. 28, pp. 1967-1978.

García-García, A., García-Gil, S., and Vilas, F., 2004, Echo characters and recent sedimentary processes as indicated by high-resolution sub-bottom profiling in Ría de Vigo (NW Spain), Geo-Marine Letters, v. 24, pp. 32-45.

Géli, L., Turon, J.-L., Aslanian, D., Balut, Y., Beuzart, P., Cochran, J., Francheteau, J., Harmegnies, F., Landuré, J.-Y., Le Suavé, R., Mazaud, A., Michel, E., Normand, A., Pichon, J.-J., and Vlastelic, I., 2001, Deeppenetration heat flow probes raise questions about interpretations from shorter probes, Eos, Transactions American Geophysical Union, v. 82, pp. 317-320.

Grantz, A., Hart, P.E., and Childers, V.A., 2011, Geology and tectonic development of the Amerasia and Canada Basins, Arctic Ocean, in Spencer, A.M., Embry, A.F., Gautier, D.L., Stoupakova, A.V., and Sørensen, K., eds., Arctic Petroleum Geology, v 35, The Geological Society of London, pp. 771-799.

Hamamoto, H., Yamano, M., and Goto, S., 2005, Heat flow measurement in shallow seas through long-term temperature monitoring: Geophysical Research Letters, v. 32, http://doi.org/10.1029/2005GL024138

Hegewald, A., and Jokat, W., 2013, Relative sea level variations in the Chukchi region - Arctic Ocean - since the late Eocene, Geophysical Research Letters, v. 40, pp. 803-807.

Himmler, T., Sahy, D., Martma, T., Bohrmann, G., Plaza-Faverola, A., Bünz, S., Condon, D.J., Knies, J., and Lepland, A., 2019, A 160,000-year-old history of tectonically controlled methane seepage in the Arctic, Science Advances, v. 5, pp. 1450.

Hong, W.-L., Torres, M.E., Carroll, J., Crémière, A., Panieri, G., Yao, H., and Serov, P., 2017, Seepage from an arctic shallow marine gas hydrate reservoir is insensitive to momentary ocean warming, Nature Communications, v. 8, pp. 15745 .
Hovland, M., and Curzi, P.V., 1989, Gas seepage and assumed mud diapirism in the Italian central Adriatic Sea, Marine and Petroleum Geology, v. 6, pp. 161-169.

Ilhan, I., and Coakley, B.J., 2018, Meso-Cenozoic evolution of the southwestern Chukchi Borderland, Arctic Ocean, Marine and Petroleum Geology, v. 95, pp. 100-109.

International Hydrographic Organization, 1953, Limits of Oceans and Seas, International Hydrographic Organization, Sepcial Publication, $39 \mathrm{p}$.

Jakobsson, M., 2002, Hypsometry and volume of the Arctic Ocean and its constituent seas, Geochemistry, Geophysics, Geosystems, v. 3, pp. 1-18.

Jakobsson, M., Andreassen, K., Bjarnadóttir, L.R., Dove, D., Dowdeswell, J.A., England, J.H., Funder, S., Hogan, K., Ingólfsson, Ó., Jennings, A., Krog Larsen, N., Kirchner, N., Landvik, J.Y., Mayer, L., Mikkelsen, N., Möller, P., Niessen, F., Nilsson, J., O'Regan, M., Polyak, L., Nørgaard-Pedersen, N., and Stein, R., 2014, Arctic Ocean glacial history, Quaternary Science Reviews, v. 92, pp. 40-67.

Jakobsson, M., Mayer, L., Coakley, B., Dowdeswell, J.A., Forbes, S., Fridman, B., Hodnesdal, H., Noormets, R., Pedersen, R., Rebesco, M., Schenke, H.W., Zarayskaya, Y., Accettella, D., Armstrong, A., Anderson, R.M., Bienhoff, P., Camerlenghi, A., Church, I., Edwards, M., Gardner, J.V., Hall, J.K., Hell, B., Hestvik, O., Kristoffersen, Y., Marcussen, C., Mohammad, R., Mosher, D., Nghiem, S.V., Pedrosa, M.T., Travaglini, P.G., and Weatherall, P., 2012, The International Bathymetric Chart of the Arctic Ocean (IBCAO) Version 3.0, Geophysical Research Letters, v. 39, pp. L12609.

Jin, Y.K., Kim, Y.-G., Baranov, B., Shoji, H., and Obzhirov, A., 2011, Distribution and expression of gas seeps in a gas hydrate province of the northeastern Sakhalin continental slope, Sea of Okhotsk: Marine and Petroleum Geology, v. 28, pp. 1844-1855.

Jin, Y.K., and Onboard ship scientific party, 2017, ARA07C Cruise Report: 2016 Korea-Russia-Germany East Siberian Sea Research Program, Korea Polar Research Institute, KIOST, BSPM16050-080-3.

Jin, Y.K., and Shipboard scientific party, 2019, ARA09C Cruise Report: 2018 Korea-Russia-Japan East Siberian/Chukchi Sea Research Program, Korea Polar Research Institute, BSPM18050-019-3.

Kennett, J.P., Cannariato, K.G., Hendy, I.L., and Behl, R.J., 2003, Methane Hydrates in Quaternary Climate Change: The Clathrate Gun Hypothesis, American Geophysical Union, AGU Special Publications.

Kim, J.-H., Torres, M.E., Hong, W.-L., Choi, J., Riedel, M., Bahk, J.-J., and Kim, S.-H., 2013a, Pore fluid chemistry from the Second Gas Hydrate Drilling Expedition in the Ulleung Basin (UBGH2): Source, mechanisms and consequences of fluid freshening in the central part of the Ulleung Basin, East Sea, Marine and Petroleum Geology, v. 47, pp. 99-112.

Kim, Y.-G., Lee, S.-M., Jin, Y.K., Baranov, B., Obzhirov, A., Salomatin, A., and Shoji, H., 2013b, The stability of gas hydrate field in the northeastern continental slope of Sakhalin Island, Sea of Okhotsk, as inferred from analysis of heat flow data and its implications for slope failures, Marine and Petroleum Geology, v. 45, pp. 198-207.

Kim, Y.-G., Kim, H.J., Kim, S., Lee, I., Kim, J.-H., Lee, D.-H., Kang, S.-G., and Jin, Y.K., Gas Hydrate Mounds in the Eastern Slope of the Chukchi Basin, Arctic Ocean: Indicators of Methane-rich Focused Fluid Flow, in Proceedings 19th EGU General Assembly, Vienna, Austria, 2017.

Kim, J.-H., Hachikubo, A., Kida, M., Minami, H., Lee, D.-H., Jin, Y.K., Ryu, J.-S., Lee, Y.M., Hur, J., Park, M.-H., Kim, Y.-G., Kang, M.-H., Park, S., Chen, M., Kang, S.-G., and Kim, S., 2020, Upwarding gas source and postgenetic processes in the shallow sediments from the ARAON Mound, Chukchi Sea: Journal of Natural Gas Science and Engineering, v. 76, 103223, http://doi.org/10.1016/j.jngse.2020.103223.

Klauda, J.B., and Sandler, S.I., 2005, Global Distribution of Methane Hydrate in Ocean Sediment, Energy \& Fuels, v. 19, pp. 459-470.

Kolesnik, O. N., Kolesnik, A. N., and Pokrovskii, B. G., 2014, A find of an authigenic methane-derived carbonate in the Chukchi Sea, Doklady Earth Sciences, v. 458, pp. 1168-1170. 
Kvenvolden, K.A., 1988, Methane hydrate-A major reservoir of carbon in the shallow geosphere, Chemical Geology, v. 71, pp. 41-51.

Kvenvolden, K.A., Ginsburg, G.D., and Soloviev, V.A., 1993, Worldwide distribution of subaquatic gas hydrates, Geo-Marine Letters, v. 13, pp. 32-40.

Kvenvolden, K.A., and Lorenson, T.D., 2013, The Global Occurrence of Natural Gas Hydrate, in Paull, C.K., and Dillon, W.P., eds., Natural Gas Hydrates, Occurrence, Distribution, and Detection, pp. 3-18.

Loncke, L., Mascle, J., and Fanil Scientific Parties, 2004, Mud volcanoes, gas chimneys, pockmarks and mounds in the Nile deep-sea fan (Eastern Mediterranean): geophysical evidences, Marine and Petroleum Geology, v. 21, pp. 669-689.

Machiyama, H., Kinoshita, M., Takeuchi, R., Matsumoto, R., Yamano, M., Hamamoto, H., Hiromatsu, M., Satoh, M., and Komatsubara, J., 2009, Heat Flow Distribution around the Joetsu Gas Hydrate Field, Western Joetsu Basin, Eastern Margin of the Japan Sea, Journal of Geography (Chigaku Zasshi), v. 118, pp. 986-1007.

Mazzini, A., and Etiope, G., 2017, Mud volcanism: An updated review: Earth-Science Reviews, v. 168, pp. 81-112.

McQuillin, R., Bacon, M., and Barclay, W., 1984, An introduction to seismic interpretation - Reflection seismics in petroleum exploration, Graham and Trotman Ltd.,Gaithersburg, $287 \mathrm{p}$.

Paull, C.K., Ussler, W., Dallimore, S.R., Blasco, S.M., Lorenson, T.D., Melling, H., Medioli, B.E., Nixon, F.M., and McLaughlin, F.A., 2007, Origin of pingo-like features on the Beaufort Sea shelf and their possible relationship to decomposing methane gas hydrates, Geophysical Research Letters, v. 34, pp. L01603.

Paull, C. K., Normark, W. R., Ussler Iii, W., Caress, D. W., and Keaten, R., 2008, Association among active seafloor deformation, mound formation, and gas hydrate growth and accumulation within the seafloor of the Santa Monica Basin, offshore California, Marine Geology, v. 250, pp. 258-275.

Paull, C.K., Caress, D.W., Thomas, H., Lundsten, E., Anderson, K., Gwiazda, R., Riedel, M., McGann, M., and Herguera, J.C., 2015a, Seafloor geomorphic manifestations of gas venting and shallow subbottom gas hydrate occurrences, Geosphere.

Paull, C.K., Dallimore, S.R., Caress, D.W., Gwiazda, R., Melling, H., Riedel, M., Jin, Y.K., Hong, J.K., Kim, Y.-G., Graves, D., Sherman, A., Lundsten, E., Anderson, K., Lundsten, L., Villinger, H., Kopf, A., Johnson, S.B., Hughes Clarke, J., Blasco, S., Conway, K., Neelands, P., Thomas, H., and Côté, M., 2015b, Active mud volcanoes on the continental slope of the Canadian Beaufort Sea, Geochemistry, Geophysics, Geosystems, v. 16, pp. 3160-3181.

Peckmann, J., Reimer, A., Luth, U., Luth, C., Hansen, B.T., Heinicke, C., Hoefs, J., and Reitner, J., 2001, Methane-derived carbonates and authigenic pyrite from the northwestern Black Sea: Marine Geology, v. 177, pp. 129-150.

Perez-Garcia, C., Feseker, T., Mienert, J., and Berndt, C., 2009, The Håkon Mosby mud volcano: 330000 years of focused fluid flow activity at the SW Barents Sea slope, Marine Geology, v. 262, pp. 105-115.

Petersen, C.J., Bünz, S., Hustoft, S., Mienert, J., and Klaeschen, D., 2010, High-resolution P-Cable 3D seismic imaging of gas chimney structures in gas hydrated sediments of an Arctic sediment drift, Marine and Petroleum Geology, v. 27, pp. 1981-1994.

Roberts, A.M., and Yielding, G., 1991, Deformation around basin-margin faults in the North Sea/mid-Norway rift, Geological Society, London, Special Publications, v. 56, pp. 61-78.

Roberts, H.H., 2001, Fluid and Gas Expulsion on the Northern Gulf of Mexico Continental Slope: Mud-Prone to Mineral-Prone Responses, in Paull Charles K., and Dillon, W.P., eds., Natural Gas Hydrates, Occurrence, Distribution, and Detection, v. 124, American Geophysical Union, pp. 145-161.

Ruppel, C.D., 2011, Methane Hydrates and Contemporary Climate Change, Nature Education Knowledge, v. 3, pp. 29

Sancier, R.T., 1971, Acoustic Subbottom Profiling Systems, A State-ofthe-Art Survey, The Journal of the Acoustical Society of America, v. 49, pp. 412-413.

Sassen, R., Joye, S., Sweet, S.T., DeFreitas, D.A., Milkov, A.V., and MacDonald, I.R., 1999, Thermogenic gas hydrates and hydrocarbon gases in complex chemosynthetic communities, Gulf of Mexico continental slope, Organic Geochemistry, v. 30, pp. 485-497.

Serié, C., Huuse, M., and Schødt, N.H., 2012, Gas hydrate pingoes: Deep seafloor evidence of focused fluid flow on continental margins, Geology, v. 40, pp. 207-210.

Shakhova, N., Semiletov, I., Salyuk, A., Yusupov, V., Kosmach, D., and Gustafsson, Ö., 2010, Extensive Methane Venting to the Atmosphere from Sediments of the East Siberian Arctic Shelf, Science, v. 327, pp. 1246-1250.

Sloan Jr., E.D., and Koh, C.A., 2007, Clathrate Hydrates of Natural Gases, CRC Press, Chemical Industries Series, v. 119.

Sloan, L.C., Walker, J.C.G., Moore, T.C., Rea, D.K., and Zachos, J.C., 1992, Possible methane-induced polar warming in the early Eocene, Nature, v. 357, pp. 320-322.

Somoza, L., León, R., Medialdea, T., Pérez, L.F., González, F.J., and Maldonado, A., 2014, Seafloor mounds, craters and depressions linked to seismic chimneys breaching fossilized diagenetic bottom simulating reflectors in the central and southern Scotia Sea, Antarctica, Global and Planetary Change, v. 123, pp. 359-373.

Vadakkepuliyambatta, S., 2019, A graphical user interface for estimating the gas hydrate stability in marine sediments, in Centre for Arctic Gas Hydrate, E., and Climate, eds., Dataverse NO.

Waage, M., Portnov, A., Serov, P., Bünz, S., Waghorn, K.A., Vadakkepuliyambatta, S., Mienert, J., and Andreassen, K., 2019, Geological Controls on Fluid Flow and Gas Hydrate Pingo Development on the Barents Sea Margin, Geochemistry, Geophysics, Geosystems, v. 20, pp. 630-650.

Wang, R., Xiao, W., Shao, L., Chen, J., and Gao, A., 2012, Paleoceanographic records in the Chukchi Basin, western Arctic Ocean during the late Quaternary, Acta Oceanologica Sinica, v. 31, pp. 83-94.

Wang, R., Xiao, W., März, C., and Li, Q., 2013, Late Quaternary paleoenvironmental changes revealed by multi-proxy records from the Chukchi Abyssal Plain, western Arctic Ocean, Global and Planetary Change, v. 108, pp. 100-118.

Wilson, R.M., Macelloni, L., Simonetti, A., Lapham, L., Lutken, C., Sleeper, K., D'Emidio, M., Pizzi, M., Knapp, J., and Chanton, J., 2014, Subsurface methane sources and migration pathways within a gas hydrate mound system, Gulf of Mexico, Geochemistry, Geophysics, Geosystems, v. 15 , pp. 89-107.

Xu, W., and Ruppel, C., 1999, Predicting the occurrence, distribution, and evolution of methane gas hydrate in porous marine sediments: Journal of Geophysical Research, Solid Earth, v. 104, pp. 5081-5095. 


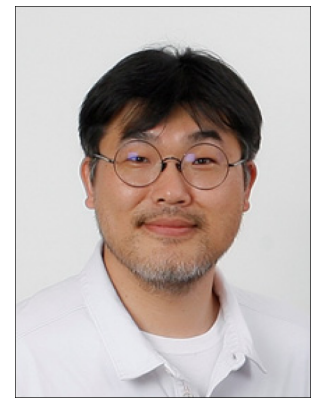

Young-Gyun Kim is a research professor at the Research Institute for Earth Resources, Kangwon National University. He received his Ph. D. from Seoul National University in 2013. He has been working to postulate seeping activity, distribution, and origin of the cold seeps associated with methane-rich gas in the East Sea, Sea of Okhotsk, and the Arctic Ocean, mainly using marine heat flow and various acoustic survey results. He is also involved in modeling studies related to the opening of rifting basins such as the Ulleung Basin in the East Sea and the Adare Basin in the Ross Sea (Antarctica)

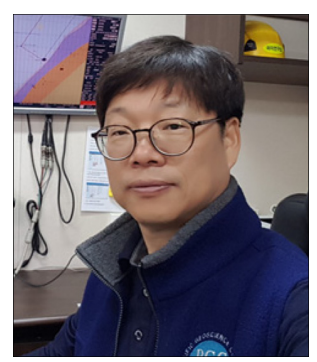

Young Keun Jin is a principal researcher at the Korea Polar Research Institute. He received his $\mathrm{Ph}$. D. in geophysics from the Seoul National University in 1995. He has led the Korea Arctic Marine Geoscience Expedition (AMAGE) program (2016-2021). His research focuses on investigating marine geological/tectonic structures, occurrence and behavior of gas hydrates in Polar Seas, and methane release due to degradation of Arctic seabed permafrost and gas seepage activities, using geophysical and geochemical methods. 